\title{
QUALITY ASPECTS OF PAN BREAD PREPARED BY PARTIAL SUBSTITUTION OF WHEAT FLOUR WITH DEFATTED RICE BRAN
}

\author{
A.S. Sallam, A.H. Khalil, M.M. Mostafa, A.A. El Bedawy and Aml A. Atef \\ Food Science and Technology Department, Faculty of Agriculture, Menoufia University, \\ Shibin El-Kom, Egypt
}

Received: Apr. 2, 2019

Accepted: May 2, 2019

\begin{abstract}
In recent years, there is a growing interest towards the consumption of highly nutritive and healthy food to fulfill the consumer demands. Rice bran, a byproduct of rice milling industry, is a rich source for dietary fiber, protein, minerals, fat, vitamins and antioxidants and hence can be utilized as functional ingredient. Therefor the current study focused on using defatted rice bran (DRB) as partial substitute of wheat flour in the preparation of pan bread. The quality attributes of pan bread were evaluated. The results indicated that composite pan bread made with DRB had higher $(p \leq 0.05)$ moisture, crude protein, crude fiber and ash contents than control bread. Increasing the substitution level with DRB resulted in lower $(p \leq 0.05)$ loaf volume, height and specific volume compared to control. The crust and crumb colors of composite bread were darker, more reddish and yellowish colored than control. Textural analysis of composite bread exhibited higher $(p \leq 0.05)$ hardness, chewiness and gumminess and lower $(p \leq 0.05)$ cohesiveness, springiness and resilience than control bread. Control bread as well as bread made with $5 \%$ DRB showed the highest $(p \leq 0.05)$ overall acceptability scores. Also, bread made with $10 \%$ DRB was overall acceptable by panelists. The results revealed that DRB could be incorporated in bread formula up to $10 \%$ to produce organoleptically acceptable and more nutritious bread compared to control.
\end{abstract}

Key words: Defatted rice bran, pan bread, Functional ingrediant, Quality attributes.

\section{INTRODUCTION}

Nowadays, there is increasing interest towards the use of natural substances present in foods as a source of functional ingredients to produce nutritive and healthy foods and fulfilled the consumer demands. Rice bran is an inexpensive byproduct obtained from rice milling industry. It constitutes $8 \%$ of the weight of the whole grain and contains most of the nutrients (Tuncel, 2014). The increase in crude fiber might play an important role in the prevention of many diseases such as coronary heart diseases, diabetes, gut neoplasia, constipation and colon cancer (Dreher, 2001). Rice bran appears as light brown, slightly oily and unstable meal. Due to the presence of lipase enzyme in rice bran, deterioration of the crude fat occurred directly following the milling process. Therefore, it becomes necessary to inactivate lipase enzyme to make bran fit for human consumption. Various stabilization methods have been reported to inactivate lipase enzyme (Brunschwiler et al., 2013, Lakkakula et al., 2004).

Rice bran possesses important components such as proteins, minerals, soluble and insoluble dietary fiber, fats and phytochemicals that supply beneficial health effect on the human body (Rafe et al., 2016). Lebesi and Tzia (2011) reported that rice bran contains about $45-50 \%$ total dietary fiber, $37-40 \%$ insoluble and $9-10 \%$ soluble dietary fiber, $14-15 \%$ protein and $18-20 \%$ fat. Also, rice 
bran protein is composed of high amount of lysine and other essential amino acids which make it important in the fortification of wheat flour in bread making to increase protein quality by improving its amino acid profiles (Sudarat et al., 2005). Defatting of rice bran markedly increases the proportion of dietary fiber and crude protein contents (Iqbal et al., 2005). The nutritive value and health benefits of rice bran have been documented (Sharma and Chauhan, 2002). Also, James and Sloan (1984) indicated that defatted rice bran might affect the quality of the bread due to the higher stability, water holding, fat holding and foaming capacities than full fat rice bran.

Due to the high nutritional value and low cost of rice bran, it could be utilized for enriching food products such as bread. Supplementation of wheat flour with rice bran as functional ingredient in bread making might increase the nutritional profile with respect to protein, lysine and dietary fiber contents. Therefor the current study was designed to incorporate different levels of defatted rice bran $(5,10,15$ and $20 \%)$ as partial substitute of wheat flour in the preparation of pan bread and evaluate its effect on quality attributes of pan bread.

\section{MATERIALS AND METHODS Materials}

Rice bran was obtained from Al Waliliy rice milling company, El Beheira Governorate, Egypt. Wheat flour (72\% extraction) was purchased from Manar Company, 6 October City, Egypt. Other ingredients like salt, sugar, yeast and baking powder were purchased from local market.

\section{Defatted rice bran}

Rice bran was extruded at $130^{\circ} \mathrm{C}$ and $30 \%$ moisture. The extruded rice bran was defatted using the AOCS (2012).
Preparation of composite flour blends

Four composite flour blends were prepared by partial substitution of wheat flour with $5,10,15$ and $20 \%$ defatted rice bran (DRB), while $100 \%$ wheat flour ( $0 \%$ substitutions) was used as control.

\section{Preparation of pan bread}

Straight dough method was used for pan bread production according to the method described by AACC (2002). One hundred grams of wheat flour $(72 \%$ extraction) were mixed with salt (1\%), compressed yeast (1.5\%), corn oil (5\%), and sugar (1.5\%). Water was added according to the data obtained from farinograph. All ingredients were mixed in a dough mixer to form dough. The dough was put into greased fermentation bowel and placed in fermentation cabinet at $37^{\circ} \mathrm{C}$ for 20 minutes, proofed at $40^{\circ} \mathrm{C}$ for 60 minutes and baked in electric oven at $220^{\circ} \mathrm{C}$ for 25 minutes. The loaves were separated from the metal pan and allowed to cool at room temperature before analysis.

\section{Proximate composition}

Proximate composition (moisture, crude protein, fat, total ash and crude fiber) of pan bread was determined using the method of AOAC (2012).

\section{Physical properties of pan bread}

Bread loaf volume was determined by rapeseed displacement method after cooling for $1 \mathrm{hr}$ at room temperature, while loaf weight was determined using electronic balance. Specific loaf volume was calculated (loaf volumelloaf weight). The standing height of loaf was also measured.

\section{Color measurements}

Instrumental color analysis of crust and crumb color of pan bread was conducted using a Minolta colorimeter 
CR-200 (Minolta Chroma Meter CR-200, Japan) according to the method described by Gomez et al. (2003). The color parameters were defined as $\mathrm{L}^{*}$ (measure the lightness ranging from black to white), $\mathbf{a}^{*}$ (value ranges from greenness to + redness) and $b^{*}$ (value ranges from -blueness to + yellowness). Color difference $\left(\Delta E^{*}\right)$ between control bread and bread containing defatted rice bran was calculated from the following equation

$$
\Delta \mathrm{E}^{\star}=\sqrt{\Delta \mathrm{L}^{\star^{2}}+\Delta \mathrm{a}^{*^{2}}+\Delta \mathrm{b}^{\star^{2}}}
$$

Where $\Delta L^{*}$ is the brightness difference, $\Delta a^{*}$ is the redness difference and $\Delta b^{*}$ is the yellowness difference.

\section{Texture profile analysis (TPA)}

Bread crumb texture (Hardness, cohesiveness, gumminess, chewiness, springiness and resilience) was determined using Texture Profile Analyzer (TPA) according to Bourne et al. (2003). Crumb texture was determined by universal testing machine (Conetech, B type, Taiwan) provided with software. An aluminum $25 \mathrm{~mm}$ diameter cylindrical probe was used in a TPA double compression test to penetrate to $50 \%$ depth, at $1 \mathrm{~mm} / \mathrm{s}$ speed test. Texture analysis of pan bread samples was conducted after $0,1,2,3$ days of storage at ambient temperature.

\section{Sensory evaluation of pan bread}

Sensory evaluation of pan bread samples was performed by 15 panelists who were graduate students in the Department of Food Science and Technology, Menoufia University. Sensory quality attributes (volume, texture, taste, odor, crumb color, crust color, appearance and overall acceptability) were evaluated using scoring scheme described by AACC (2002).

\section{Statistical analysis}

A completely randomized design and means separations were conducted to analyze the data of proximate composition, physical properties, color and sensory properties.

Data for texture analysis were analyzed using a completely randomized 5 T (substitution level) $\times 4$ (storage time) $x 3$ (replication) factorial design (Montgomery, 2010). Comparisons among means were performed using the LSD test. The differences were considered significant $(p \leq 0.05)$ at $5 \%$ level.

\section{RESULTS AND DISCUSSION \\ Proximate composition of composite bread}

Proximate composition of pan bread formulated by partial substitution of wheat flour with DRB is presented in Table 1. Increasing the level of substitution resulted in significant $(p \leq 0.05)$ increase in moisture content, crude protein, crude fiber and total ash contents, while crude fat was not affected $(p>0.05)$. The moisture content increased from $28 \%$ for control bread to $32.10 \%$ for bread made with $20 \%$ DRB. The increase in moisture content might be due to the high water absorption by DRB (Ajmal et al., 2006).

Total crude fiber increased significantly $(p \leq 0.05)$ from 0.60 for control bread to 6.90 for bread made with $20 \%$ DRB. It is worth to mention that the increase in moisture content of pan bread produced with DRB was found to be proportional to the concentration of fiber which might absorb water and consequently increase the levels required for producing dough of optimum consistency. Also, crude protein and total ash contents increased from 12.5 and 0.80 for control to 14.6 and 2.68 for bread prepared with $20 \%$ DRB respectively. The increases in proximate 
composition parameters of pan bread containing DRB may be due to variations in composition and ratios of wheat flour (72\% ER) and DRB. These results are in good agreement with those obtained by Hegazy and El-Khamissi (2017) and Sangle et al. (2017).

\section{Physical properties of composite bread}

Physical properties of composite bread prepared with DRB are presented in Table 2. Results showed that the loaf volume, height and specific volume decreased $(p \leq 0.05)$ gradually by increasing the level of DRB. However, the loaf weight of bread containing DRB increased $(p \leq 0.005)$ by increasing the substitution level. Sangle et al. (2017) attributed the increase in loaf weight due to the high content of crude fiber in stabilized rice bran which might bind and absorb high amount of water. The loaf height was significantly $(p \leq 0.005)$ affected by the addition of DRB. The lowest $(p \leq 0.005)$ loaf height was obtained by the addition of $20 \%$ DRB. The loaf volume and specific volume of composite breads decreased ( $p \leq 0.005$ ) from 607.25 $\mathrm{cm}^{3}$ and $3.78 \mathrm{~cm}^{3} / \mathrm{gm}$ for control bread to $462.15 \mathrm{~cm}^{3}$ and $2.73 \mathrm{~cm}^{3} / \mathrm{gm}$ for bread made with $20 \%$ DRB respectively. The decrease in loaf volume could be explained by the fact that substitution of wheat flour with DRB may cause gluten dilution and consequently, affect the optimal gluten matrix formation during mixing, formulation and baking step. Pollard et al. (2012) reported that the addition of whole wheat flour, which contains high dietary fiber and nongluten networks, into the bread formulation caused an adverse effect on carbon dioxide gas production and retention during dough proofing that exerted lower loaf volume. Moreover, Sangle et al. (2017) reported that the specific volume of composite bread decreased progressively by increasing the amount of stabilized rice bran into the formula. The simultaneous changes of a decrease in the volume and an increase in the weight of high fiber rice bran bread, which led to a decreasing trend in the specific volume changes, were reported by Bagheri and Seyedein (2011).

Table (1): Proximate composition (\%dry weight) of pan bread made from mixture of wheat flour (72\%ER) and different replacement levels of defatted rice bran.

\begin{tabular}{cccccc}
\hline & & \multicolumn{4}{c}{ proximate composition\% } \\
& Moisture & Fat & protein & Total fiber & Total ash \\
\hline Control & $28.00^{\mathrm{e}}$ & $5.20^{\mathrm{a}}$ & $12.50^{\mathrm{e}}$ & $0.60^{\mathrm{e}}$ &.,$\wedge . \mathrm{e}$ \\
$5 \% \mathrm{DRB}$ & $28.60^{\mathrm{d}}$ & $5.20^{\mathrm{a}}$ & $12.68^{\mathrm{d}}$ & $1,0 \mathrm{r}^{\mathrm{d}}$ & $1, \xi . \mathrm{d}$ \\
$10 \% \mathrm{DRB}$ & $29.40^{\mathrm{c}}$ & $5.10^{\mathrm{a}}$ & $12.85^{\mathrm{c}}$ & $3.40^{\mathrm{c}}$ & $1.75^{\mathrm{c}}$ \\
$15 \% \mathrm{DRB}$ & $30.70^{\mathrm{b}}$ & $5.10^{\mathrm{a}}$ & $13.60^{\mathrm{b}}$ & $5.55^{\mathrm{b}}$ & $2.23^{\mathrm{b}}$ \\
$20 \% \mathrm{DRB}$ & $32.10^{\mathrm{a}}$ & $5.10^{\mathrm{a}}$ & $14.60^{\mathrm{a}}$ & $6.90^{\mathrm{a}}$ & $2.68^{\mathrm{a}}$ \\
LSD & 0.02 & 0.12 & 0.06 & 0.45 & 0.05 \\
\hline
\end{tabular}

Means in the same column with different latters are significantly $(p \leq 0.05)$ different

$\mathrm{DRB}=$ Defatted rice bran 
Quality aspects of pan bread prepared by partial substitution of wheat ........

Table (2): Physical properties of pan bread prepared by partial replacement of wheat flour with different levels of defatted rice bran

\begin{tabular}{ccccc}
\hline Samples & $\begin{array}{c}\text { Height } \\
(\mathrm{Cm})\end{array}$ & $\begin{array}{c}\text { Weight } \\
(\mathrm{gm} .)\end{array}$ & $\begin{array}{c}\text { Volume } \\
\left(\mathrm{Cm}^{3}\right)\end{array}$ & $\begin{array}{c}\text { Specific volume } \\
\left(\mathrm{Cm}^{3} / \mathrm{gm} .\right)\end{array}$ \\
\hline Control & $7.24^{\mathrm{a}}$ & $160.34^{\mathrm{e}}$ & $607.25^{\mathrm{a}}$ & $3.78^{\mathrm{a}}$ \\
$5 \% \mathrm{DRB}$ & $7.25^{\mathrm{a}}$ & $163.81^{\mathrm{d}}$ & $608.33^{\mathrm{a}}$ & $3.70^{\mathrm{b}}$ \\
$10 \% \mathrm{DRB}$ & $6.48^{\mathrm{b}}$ & $165.44^{\mathrm{c}}$ & $504.62^{\mathrm{b}}$ & $3.05^{\mathrm{c}}$ \\
$15 \% \mathrm{DRB}$ & $6.25^{\mathrm{c}}$ & $167.12^{\mathrm{b}}$ & $491.87^{\mathrm{b}}$ & $2.94^{\mathrm{d}}$ \\
$20 \% \mathrm{DRB}$ & $5.94^{\mathrm{d}}$ & $169.14^{\mathrm{a}}$ & $462.15^{\mathrm{c}}$ & $2.73^{\mathrm{e}}$ \\
LSD & 0.21 & 0.23 & 16.9 & 0.07 \\
\hline
\end{tabular}

Each value in the table is the mean of three replicates.

Means in the same column with different latters are significantly $(p \leq 0.05)$ different

DRB $=$ Defatted rice bran

\section{Crust and crumb colors of composite bread \\ The crust and crumb colors of} composite bread were influenced by the level of DRB (Table 3). The results indicated that crust and crumb colors of composite bread were significantly $(p \leq 0.05)$ darker (lower $L^{*}$ values) than control (higher $L^{*}$ values). The dark color of DRB itself compared to wheat flour is responsible for the lower $L^{*}$ values of composite bread. Also, Millard reaction between reducing sugars and proteins during baking process might be responsible for the dark color as reported by Dhingra and Jood (2004). Increasing the level of DRB in composite bread resulted in significant $(p \leq 0.05)$ decrease in crust and crumb colors lightness. Majzoobi et al. (2013) reported a darker color (lower $L^{*}$ value) for cake prepared with rice bran compared to control. Crust and crumb colors of composite bread showed higher $(p \leq 0.05)$ redness $\left(a^{*}\right.$ values) and yellowness ( $b^{*}$ values) than control. Increasing the level of DRB resulted in significant $(p \leq 0.05)$ increase in redness and yellowness of crust and crumb colors. The highest redness and yellowness values of crust and crumb colors were recorded for bread containing 20\% DRB. The similar results were obtained by Anil (2012) who indicated that pide (Turkish bread) supplemented with rice bran had lower $\mathrm{L}^{*}$ values and higher $a^{*}$ and $b^{*}$ values compared to control. The crust and crumb color differences $\left(\Delta E^{*}\right)$ between composite bread and control were increased $(p \leq 0.05)$ by increasing the level of substitution. The highest $(p \leq 0.05)$ crust and crumb color differences $\left(\Delta \mathrm{E}^{*}\right)$ were found in bread made with $20 \%$ DRB which showed $\Delta E^{*}$ values 12.23 and $\mathbf{1 7 . 2 2}$ respectively.

Textural profile analysis of composite bread

As shown in Table 4, textural analysis of composite bread exhibited higher $(p \leq 0.05)$ hardness, chewiness and gumminess and lower $(p \leq 0.05)$ cohesiveness, springiness and resilience than control bread. Hardness of composite bread increased with increasing the level of DRB substitution. The highest hardness crumb value was 
obtained for bread containing 20\% DRB. The increase in hardness of composite bread may be due to the effect of fiber to restrict the expansion of gas cells producing a more compact texture which imparts to the increment of the bread hardness (Collar et al., 2007). Also, Taghinia et al. (2015) reported that the increase of hardness in bread prepared with rice bran may resulted from decreasing gluten in total formulation which caused not only transfer of moisture from core to crust but also decrease of gas cells in dough texture during fermentation. Gomez et al. (2003) reported that bread hardness was due to interactions between gluten and fibrous materials. The similar hard crumb texture results were obtained by Majzoobi et al. (2013) who observed an increase in cake hardness when rice bran was included in the formula of cake.

Cohesiveness of composite bread decreased $(p \leq 0.05)$ as the level of DRB increased. This reduction indicates that breads formulated with DRB have low ability to resist before the bread structure deformed under the teeth. Majzoobi et al. (2013) reported that the higher quantity level of rice bran results in creation of a less cohesive structure of the sponge cake.
Increasing the levels of DRB resulted in significant $(p \leq 0.005)$ increases of gumminess and chewiness. The increases in gumminess and chewiness could be attributed to changes in protein quantity and water absorption. Also, the addition of DRB, which contain high quantity of fiber, into the bread formulation might result in coarser structure and also might distorted the gas cell structure resulting in rigid network and consequently the bread became compact and heavy.

Increasing the level of substitution resulted in significant $(p \leq 0.05)$ decrease in springiness and resilience. These results are in good agreement with Ozkaya et al. (2018) who indicated that the addition of rice bran significantly decreased springiness and resilience of the bread, depending on the bran levels. According to Hoseney (1994), the interaction between gelatinized starch and gluten dough might cause dough to be more elastic and form continuous sponge structure of bread after heating. The lower amount of gluten in composite formula due to dilution by DRB might cause lower ability to hold gases which in turn cause an elasticity reduction in composite breads.

Table (3): Instrumental crust and crumb colors of pan bread made from blends of wheat flour (72\% ER) and different replacement levels of defatted rice bran

\begin{tabular}{lcccc|cccc}
\hline \multirow{2}{*}{ Samples } & \multicolumn{4}{c|}{ crust } & \multicolumn{4}{c}{ crumb } \\
\cline { 2 - 8 } & $\mathrm{L}^{*}$ & $\mathrm{a}^{*}$ & $\mathrm{~b}^{*}$ & $\Delta \mathrm{E}^{*}$ & $\mathrm{~L}^{*}$ & $\mathrm{a}^{*}$ & $\mathrm{~b}^{*}$ & $\Delta \mathrm{E}^{*}$ \\
\hline Control & $62.77^{\mathrm{a}}$ & $11.34^{\mathrm{e}}$ & $33.49^{\mathrm{c}}$ & 0 & $72.73^{\mathrm{a}}$ & $2.46^{\mathrm{e}}$ & $23.71^{\mathrm{e}}$ & 0 \\
$5 \%$ DRB & $62.10^{\mathrm{b}}$ & $12.68^{\mathrm{d}}$ & $37.38^{\mathrm{b}}$ & $4.16^{\mathrm{c}}$ & $65.88^{\mathrm{b}}$ & $3.28^{\mathrm{d}}$ & $25.03^{\mathrm{d}}$ & $7.02^{\mathrm{d}}$ \\
$10 \%$ DRB & $57.57^{\mathrm{c}}$ & $15.61^{\mathrm{c}}$ & $37.48^{\mathrm{b}}$ & $7.39^{\mathrm{b}}$ & $64.83^{\mathrm{c}}$ & $4.23^{\mathrm{c}}$ & $26.08^{\mathrm{c}}$ & $8.43^{\mathrm{c}}$ \\
$15 \%$ DRB & $57.47^{\mathrm{d}}$ & $16.11^{\mathrm{b}}$ & $38.30^{\mathrm{ab}}$ & $8.16^{\mathrm{b}}$ & $62.17^{\mathrm{d}}$ & $5.13^{\mathrm{b}}$ & $26.15^{\mathrm{b}}$ & $11.16^{\mathrm{b}}$ \\
$20 \%$ DRB & $57.27^{\mathrm{e}}$ & $18.03^{\mathrm{a}}$ & $39.21^{\mathrm{a}}$ & $12.23^{\mathrm{a}}$ & $56.17^{\mathrm{e}}$ & $6.41^{\mathrm{a}}$ & $27.88^{\mathrm{a}}$ & $17.22^{\mathrm{a}}$ \\
LSD & 0.03 & 0.4 & 1.18 & 1.25 & 0.18 & 0.02 & 0.03 & 0.16 \\
\hline \hline
\end{tabular}

Means in the same column with different latters are significantly $(p \leq 0.05)$ different $\mathrm{DRB}=$ Defatted rice bran 
Quality aspects of pan bread prepared by partial substitution of wheat ........

Table (4): Texture profile analysis of composite bread as influenced by defatted rice bran (DRB) levels and storage time:

\begin{tabular}{|c|c|c|c|c|c|c|c|c|c|c|c|}
\hline \multirow{2}{*}{ Property } & \multicolumn{7}{|c|}{ 'DRB levels \% } & \multicolumn{4}{|c|}{ Storage time (Day) } \\
\hline & $0 \%$ & $5 \%$ & $10 \%$ & $\% 10$ & $20 \%$ & LSD & 0 & 1 & 2 & 3 & LSD \\
\hline $\begin{array}{l}\text { Hardness } \\
\text { (N) }\end{array}$ & $9.72^{\mathrm{e}}$ & $13.28^{d}$ & $14.11^{\mathrm{c}}$ & $25.57^{b}$ & $30.23^{a}$ & 0.02 & $14.22^{d}$ & ${ }^{d} 18.02^{c}$ & $20.44^{b}$ & $43.17^{a}$ & 1.01 \\
\hline $\begin{array}{l}\text { Cohesiveness } \\
\text { (s) }\end{array}$ & $0.82^{\mathrm{a}}$ & $0.80^{b}$ & $0.71^{\mathrm{c}}$ & $0.69^{d}$ & $0.65^{\mathrm{e}}$ & 0.01 & $0.81^{a}$ & $0.62^{b}$ & $0.51^{c}$ & $0.38^{d}$ & 0.04 \\
\hline $\begin{array}{l}\text { Gumminess } \\
\text { (N) }\end{array}$ & $8.03^{e}$ & $9.20^{d}$ & $11.16^{c}$ & $18.35^{b}$ & $21.38^{a}$ & 0.02 & $10.92^{\mathrm{d}}$ & ${ }^{d} 15.32^{c}$ & $19.34^{b}$ & $21.38^{a}$ & 0.28 \\
\hline $\begin{array}{l}\text { Chewiness } \\
(\mathrm{Nm})\end{array}$ & $27.71^{e}$ & $47.51^{d}$ & $51.51^{\mathrm{c}}$ & $153.22^{b}$ & $180.12^{\mathrm{a}}$ & 0.03 & $18.15^{d}$ & ${ }^{d} 27.58^{c}$ & $41.26^{b}$ & $68.02^{a}$ & 0.03 \\
\hline $\begin{array}{l}\text { Springiness } \\
(\mathrm{mm})\end{array}$ & $8.43^{a}$ & $8.01^{b}$ & $6.46^{c}$ & $5.20^{d}$ & $4.59^{e}$ & 0.02 & $5.2^{\mathrm{a}}$ & $4.48^{b}$ & $3.21^{\mathrm{c}}$ & $1.64^{d}$ & 0.06 \\
\hline resilience & $0.41^{a}$ & $0.38^{a}$ & $0.34^{b}$ & $0.30^{c}$ & $0.25^{d}$ & 0.03 & $0.41^{\mathrm{a}}$ & $0.31^{\mathrm{b}}$ & $0.25^{c}$ & $0.15^{d}$ & 0.05 \\
\hline
\end{tabular}

Means in the same row with different letters are significantly $(p \leq 0.05)$ different

${ }^{1}$ DRB= Defatted rice bran

Texture properties of composite bread formulated with DRB were influenced $(p \leq 0.05)$ by storage time. Pan bread stored for 3 days showed higher ( $p \leq 0.05)$ hardness, gumminess and chewiness and lower $(p \leq 0.05)$ cohesiveness, springiness and resilience than fresh pan bread. Also, as the storage time increased gradual increases ( $p \leq 0.05$ ) in hardness, gumminess and chewiness as well as gradual decreases $(p \leq 0.05)$ in cohesiveness, springiness and resilience were observed.

\section{Sensory properties of composite bread}

Sensory scores of composite bread formulated with DRB are shown in Table 5 . The non- significant $(p>0.05)$ difference in all sensory attributes were observed between control bread prepared by $5 \%$ DRB except for texture. However, at higher levels of DRB, all sensory attributes of composite bread were significantly $(p \leq 0.05)$ decreased as compared with control bread. The major decrease in volume scores was observed in bread made with 15 and 20\% DRB. The decrease in volume score of pan bread due to addition of rice bran was reported by Bagheri and Seyedein (2011). In term of texture evaluation, panelists recorded lower $(p \leq 0.05)$ rating scores for bread made with DRB as compared to control. The score of texture decreased as the level of DRB increased. Panelists observed surface roughness and dryness as well as coarse crumb in bread 
formulated with the highest level of DRB. The reduction in texture rating score was attributed to the compact structure of bread due to lower protein and higher fiber contents in bread made with DRB. Hard crumb texture caused by increased fiber from stabilized rice bran substitution was reported by Ameh et al. (2013). Crust and crumb colors appeared to be a very important criterion for initial acceptability of the bread by the consumer. Pan bread prepared with DRB at the highest substitution level (20\%) had the lowest ( $p \leq 0.05)$ crust and crumb color scores indicating that dark color was not attractive at higher substitution levels. Decreases in color scores with higher percentages may be due to the Egyptian panelists who usually prefer white rather than darker bread (Abu EIMaati, 1999). The dark crust and crumb colors of bread fortified with stabilized rice bran have been reported by Ameh et al. (2013). The brownish bread color appeared in this study could be directly related to the increase in fiber content. The similar taste, odor and appearance rating scores were reported by Hegazy and El-khamissi (2017) for bread made with rice bran. Control bread as well as bread made with 5\% DRB showed the highest $(p \leq 0.05)$ overall acceptability scores. Also, bread made with $10 \%$ DRB was overall acceptable by panelists. Increasing the level of DRB more than $10 \%$ in bread formula resulted in bread with low overall acceptability scores which could be attributed to the fact that panelists have been acquainted to the quality attributes of control bread.

\section{CONCLUSION}

The bread made with DRB as low cost by-product will be superior in nutritional quality and provide more health benefits than control bread. Our results suggest that wheat flour could be substituted with DRB at levels up to $10 \%$ to produce acceptable and nutritious functional bread.

Table (5): Sensory evaluation of pan bread produced from blends of wheat flour (72\% ER) and different replacement levels of defatted rice bran

\begin{tabular}{|c|c|c|c|c|c|c|c|c|}
\hline Sample & $\begin{array}{c}\text { Volume } \\
\text { (10) }\end{array}$ & $\begin{array}{c}\text { Texture } \\
\text { (20) }\end{array}$ & $\begin{array}{c}\text { Taste } \\
\text { (10) }\end{array}$ & $\begin{array}{l}\text { Oder } \\
(10)\end{array}$ & $\begin{array}{c}\text { Crumb } \\
\text { color } \\
(20)\end{array}$ & $\begin{array}{c}\text { Crust } \\
\text { color } \\
(20)\end{array}$ & $\begin{array}{c}\text { Appearance } \\
\text { (10) }\end{array}$ & $\begin{array}{c}\text { Overall } \\
\text { acceptability }\end{array}$ \\
\hline cont. & $9.30^{\mathrm{a}}$ & $19.20^{\mathrm{a}}$ & $9.10^{\mathrm{a}}$ & $9.30^{\mathrm{a}}$ & $19.00^{\mathrm{a}}$ & $18.50^{\mathrm{a}}$ & $9.10^{\mathrm{a}}$ & $89.80^{\mathrm{a}}$ \\
\hline 5\%DRB & $8.90^{a}$ & $17.40^{b}$ & $8.30^{\mathrm{a}}$ & $8.80^{\mathrm{a}}$ & $18.20^{\mathrm{a}}$ & $17.90^{\mathrm{a}}$ & $9.40^{\mathrm{a}}$ & $86.60^{a}$ \\
\hline 10\%DRB & $7.90^{\mathrm{b}}$ & $16.80^{b}$ & $7.10^{b}$ & $7.70^{b}$ & $16.50^{b}$ & $16.60^{b}$ & $8.30^{\mathrm{b}}$ & $81.30^{b}$ \\
\hline 15\%DRB & $6.70^{c}$ & $15.6^{c}$ & $6.50^{b}$ & $6.80^{c}$ & $15.00^{c}$ & $15.00^{c}$ & $7.20^{c}$ & $77.70^{c}$ \\
\hline 20\%DRB & $5.50^{d}$ & $15.10^{c}$ & $6.20^{b}$ & $6.30^{c}$ & $14.00^{d}$ & $14.20^{c}$ & $6.10^{d}$ & $73.10^{d}$ \\
\hline LSD & 0.80 & 1.17 & 0.92 & 0.80 & 0.90 & 1.13 & 0.80 & 3.20 \\
\hline
\end{tabular}

Means in the same column with different letters are significantly $(p \leq 0.05)$ different 


\section{REFERENCES}

AACC (2002). Approved method of American Association of Cereal Chemists. Am. Assoc. Cereal Chem. Inc., St. Paul., Minnesota, USA.

Abu EL-Maati, S. M. (1999). Orange processing wastes as sources of dietary fiber in white pan bread. Zagazig J. Agric. Res. 26: 381-390.

Ajmal, M., M. S. Butt, K. Sharif, M. Nasir and M. T. Nadeem (2006). Preparation of fiber and mineral enriched pan bread by using defatted rice bran. Intern. J. of Food Properties. 9: 623636.

Ameh, M.O., D. I. Gernah and B. D. Igbabul (2013). Physico-chemical and sensory evaluation of wheat bread supplemented with stabilized undefatted rice bran. Food and Nutr. Sci. 4: 43-48.

Anil, M. (2012). Effects of wheat bran, corn bran, rice bran and oat bran supplementation on the properties of pide. J. of Food Proc. and Preserv. 36: 276-283.

AOAC (2012). Official Methods of Analysis of the Association of Official Analytical Chemists, $17^{\text {th }}$ Ed. Washington, D. C.

AOCS (2012). Official methods and recommended practices of the AOCS. Champain, American Oil Chemists Society.

Bagheri, R. and S. M. Seyedein (2011). The effect of adding rice bran fibre on wheat dough performance and bread quality. World Appl. Sci. J. 14: 121125.

Bourne, M. S., A. D. Neely, J. F. Mills and K. W. Platts (2003). Implementing performance measurement systems: a literature review. Internat. J. of Business. Performance Management 5: 1-24.
Brunschwiler, C., D. Heine, S. Kappeler, B. Conde-Petit and L. Nystrcom (2013). Direct measurement of rice bran lipase activity for inactivation kinetics and storage stability prediction. J. Cereal Sci. 58: 272-277.

Collar, C., E. Santos and C. M. Rosell (2007). Assessment of the rheological profile of fiber-enriched bread doughs by response surface meth. J. of Food Eng. 78: 820-826.

Dhingra, S. and S. Jood (2004). Effect of flour blending on functional, baking and organoleptic characteristics of bread. Internat. J. of Food Sci. and Technol. 39: 213-222.

Dreher, M. L. (2001). Dietary fiber overview. In: McClary, B.V., Prosky, L. (Eds.), Advanced Dietary Fiber Technol. Blackwell Sci., Oxford, UK, PP. 1-16.

Gomez, M., F. B. Ronda, P. Caballero and A. Apesteguia (2003). Effect of dietary fiber on dough rheology and bread quality. Europ. Food Res. and Technol. 216: 51-56.

Hegazy, A. I. and H. A. Z. El-khamissi (2017). Nutritional protein quality evaluation of wheat bread supplemented by rice bran flour. J. Biol. Chem. Environ. Sci. 12: 321-333.

Hoseney, R. C. (1994). Principals of Cereal Science and Technology. $2^{\text {nd }}$ Edition, American Asso. Cereal Chem. Inc., Minnesota.

lqbal, S., M. I. Bhanger and F. Anwar (2005). Antioxidant properties and components of some commercially available varieties of rice bran in Pakistan. Food Chem. 93:265-272.

James, C. and S. Sloan (1984). Functional properties of edible rice bran in model systems. J. Food Sci. 29:310.

Lakkakula, N. R., M. Lima and T. Walker (2004). Rice bran stabilization and rice bran oil extraction using ohmic 
A.S. Sallam, et al.,

heating. Bioresource Tech. 92: 157 161.

Lebesi, D. M. and C. Tzia (2011). Effect of the addition of different dietary fiber and edible cereal bran sources on the baking and sensory characteristics of cupcakes. Food Bioproc. Technol. 4: 710-722.

Majzoobi, M., S. Sharifi, B. Imani and A. Farahnaky (2013). The effect of particle size and level of rice bran on the batter and sponge cake properties. J. Agr. Sci. Tech. 15:11751184.

Montgomery, D. C. (2010). Introduction to factorial design. Design and analysis of Experiments, Minitab Manual. John Wiley and Sons. USA. 27-34.

Ozkaya, B., B. Baumgartner and H. Ozkaya (2018). Effects of concentrated and dephytinized wheat bran and rice bran addition on bread properties. J Texture Stud. 49:84-93.

Pollard, N. J., F. L. Stoddard, Y. Popineau, C. W. Wrigley and F. MacRitchie (2012). Lupin flours as additives. Dough making, bread making, emulsifying and foaming. Cereal Chem. 79: 662-669.

Rafe, A., S. Alireza and S. Z. HoseiniYazdi (2016). Physicochemical, functional and nutritional characteristics of stabilized rice bran from tarom cultivar. Food Sci. and Nutri. 1-8.

Sangle, J. K., A. R. Sawate, B. M. Patil and R. B. Kshirsagar (2017). Nutritional and sensory quality of wheat bread supplemented with stabilized rice bran. Food Sci. Res. J. 8: 112-118.

Sharma, H. R. and G. S. Chauhan (2002). Effects of stabilized rice bran fenugreek blends on the quality of breads and cookies. J. Food Sci. Technol. 39: 225-233.

Sudarat, J., V. Srijesdaruk and W. J. Harper (2005). Extraction of rice bran protein concentrate and its application in bread. Songklanakarin J. Sci. Technol. 27: 55-64.

Taghinia, P., E. Ataye-Salehi and Z. Sheikholeslami (2015). Impact of pretreated rice bran on wheat dough performance and barbari bread quality. J. Agric. Sci. Tech. 17: 135144.

Tuncel, N. B. (2014). The effect of infrared stabilized rice bran substitution on $B$ vitamins, minerals and phytic acid content of pan breads. J. of Cereal Sci. 59: 162-166. 
جوانب الجودة لخبز القوالب المعد بالإستبدال الجزئى لاقيق القمح بواسطة رجيع الكون المنزوع الدهن

أبوبكر سلام شافعى سلام، على حسن خليل، محمود محمد مصطفى،

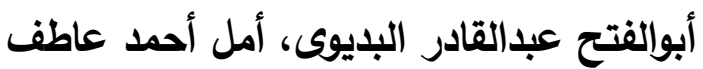

قسم علوم وتكنولوجيا الأغذية - كلية النزاعة - جامعة المنوقية المئ

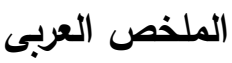

إزداد الإهتمام فى الآونة الأخيرة باستهلاك الأغذية الصحية عالية القيمة الغذائية والتى تفى بمتطلبات المستهلكين.

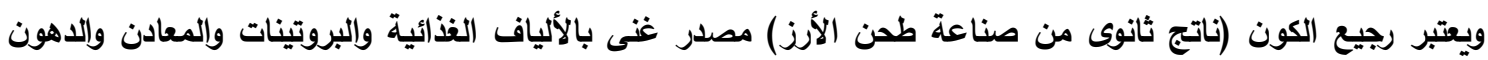

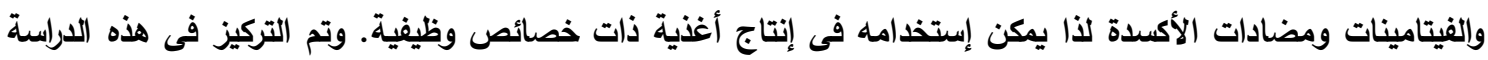

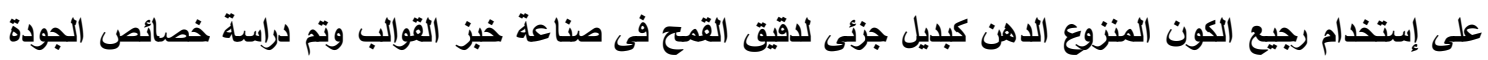

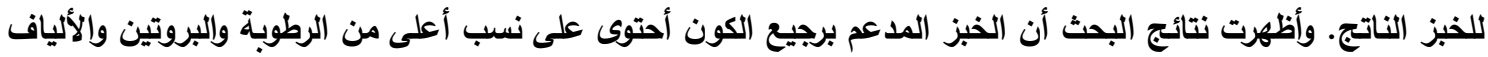
الغذائية والرماد من مثيلاتها فى خبز الكونترول, كذلك كان حجم الخبز وإرتفاعه والحجم النسبى اكبر من الكونترول. كان

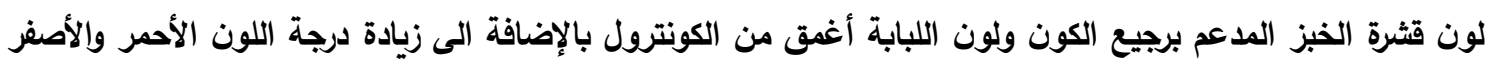

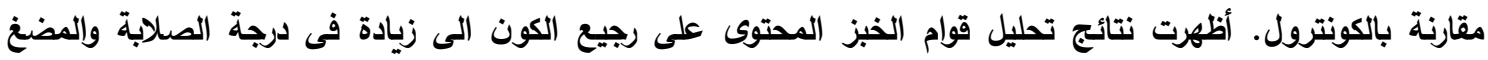

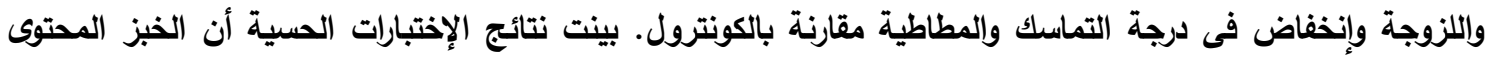
على نسبة ه\% من رجيع الكون المنزوع الدهن كان مماثلا للكونترول فى درجة القبول الكلية, أيضا كان الخبز المحتوى

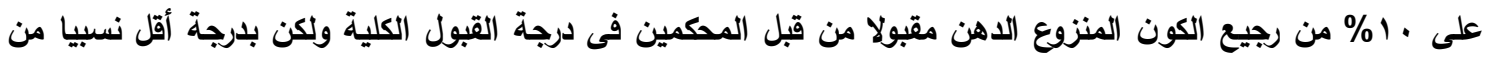

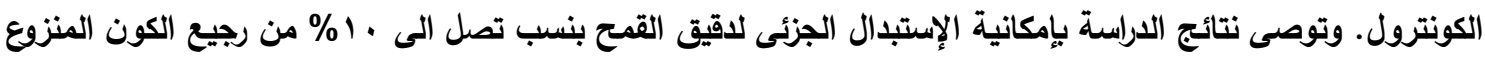
الاهن لإنتاج خبز غنى بالقيمة الغذائية ومقبول من حيث الخواص الحسية.

كلية الأقتصاد المنزلى - جامعة المنوفية 
A.S. Sallam, et al., 